\title{
An overview of potential multipurpose agroforestry tree species, Syzygium cuminii (L.) Skeels in India
}

\author{
S. Sarvade* D.S. Gautam, S. Bhalawe and P. K. Bisen \\ College of Agriculture, Balaghat- 481 331, Jawaharlal Nehru Krishi VishwaVidyalaya, Jabalpur (MP), INDIA \\ *Corresponding author. E-mail: somanath553@gmail.com
}

Received: September 22, 2015; Revised received: March 26, 2016; Accepted: July 05, 2016

\begin{abstract}
Jamun (Syzygium cuminii L.) Skeels) is evergreen MPTs (Multipurpose Tree species) widely grown in traditional agroforestry systems (agri-silviculture and agri-horticulture) of India, except very dry areas. It produces excellent nutritious fruits, which contains carbohydrates, dietary fibre, fat, protein, vitamins like B1, B2, B3, B6 and C with trace minerals (calcium, iron, magnesium, phosphorus, potassium and sodium). The seed and bark is used to control dysentery and hyperglycaemia, and in diabetic patients. Leaves of the Jamun are used in strengthening the teeth and gums, whereas fruits used in relief for colic, stomach-ache and enlarged spleen. It may accelerate work towards food security through extra food production from degraded and waste areas. The species is widely used for reclamation of salt affected soils and waterlogged areas. Their contribution in environmental conservation through biomass production and carbon sequestration processes. It also helps in conserving biodiversity in traditional agroforestry systems and natural forest areas.
\end{abstract}

Keywords: Biodiversity, Biomass production and Carbon sequestration, Food security, Jamun, MPTs, Salt affected soils, Traditional agroforestry systems

\section{INTRODUCTION}

Syzygium cuminii (L.) Skeels (Syn. Eugenia jambolana, E. cuminii and Syzygium jambolana) is a medium-sized tropical and sub-tropical evergreen tree species belongs to family Myrtaceae; commonly known as Jamun in Hindi. The tree may attain a height of 10-30 m, with a straight to crooked, short, stout trunk, $40-100 \mathrm{~cm}$ in diameter and irregular or globular crown. Bark is pale brown or dark grey, fairly smooth and $2.5 \mathrm{~cm}$ thick; inner bark is thin green outer layer, mottled light brown, astringent and bitter to the taste. Twigs are light green, becoming light grey, slightly flattened and hairless. Leaves are 7-18 cm long, 3-9 $\mathrm{cm}$ broad, opposite, thick, coriaceous, glabrous, broadly obovate, elliptic or elliptic-oblong. Flowers are dirty white or pink, slightly fragrant, nearly stalkless, arranged in threes in trichotomous panicles. Fruits are variable in size, selected cultivated varieties have larger fruits generally ovoid-oblong or elliptical berries, crowded in clusters, almost stalkless along twigs at the back of leaves. Fruits are green at first, turned in to pink and then finally purple-black in colour. Pulp is greyish-yellow, white or pale violet. The seed in each berry is strongly astringent and slightly bitter, 1-2 cm long; sometimes 2-5 angular, irregularly shaped seeds are compressed together into a mass resembling a single seed (Luna, 2005; Orwa et al., 2009). Varieties and cultivars: Variety Caryophyllifolia is smaller and branchier tree with smaller leaves and tiny barriers as compared to Axillare (grown in Western Ghats of Kerala). Improved variety Konkan Bahdolihas been recommended for cultivation in Maharashtra. The cultivar namely 'Ra Jamun' with big sized fruits is being cultivated widely Northern Parts of India. The 'Jambu Naval' cultivar is cultivated in Tamil Nadu (Sekhar et al., 2015).

Distribution: Jamun is one of the most widely distributed trees of India, occurring in the major forest groups except in the very arid regions. It may grows in both moist and dry areas, occurring in the tropical wet evergreen, tropical semi evergreen, tropical moist deciduous, littoral and swamp, tropical dry deciduous, tropical dry evergreen, subtropical broadleaved hills, and subtropical pine forests (Roy et al., 2015). The tree favours moist, damp or marshy situations, where it tends to form gregarious crops. It tolerates prolonged flooding, and once established, it can tolerate drought. In dry sites, it generally confines itself to the vicinity of watercourses. It can grow on shallow and rocky soils. Jamun is frost hardy at mature and sensitive at young stage of growth. Seedlings are readily killed by fire, but saplings and trees survive in ground fire. In the Himalayan valleys, it ascends to about $1200 \mathrm{~m}$ and in the Nigrils to $1800 \mathrm{~m}$. Biophysical limits of the species are 0-1800 masl (above sea level) elevation, 2-48 $\mathrm{C}$ mean annual temperature and 900-1 $200 \mathrm{~mm}$ mean annual rainfall (Luna, 2005; Orwa et al., 2009).

Soil type: Jamun occurs in a great variety of soils and geological formations: alluvial and colluvial soils of 
clayey to loamy texture. Such wide tolerance suggests many varieties, some of which will tolerate saline soils; it is commonly found on deep, rich, well-drained soils (Luna, 2005; Orwa et al., 2009).

Regeneration: Species is profusely regenerated from seeds around mother tree on moist grounds naturally. Each fruit may produce 1-5 seedlings in cluster. The number of seeds per kilogram vary from 1200-1800, whereas germination capacity from 20-90 per cent and plant percent of 56-96 per cent. The species can be propagated by direst sowing, by planting out seedlings and by stump planting. Air-layering with auxin is also possible (Luna, 2005).

Intercropping: Jamun is grown advantageously with banana, coffee and cocoa (Orwa et al., 2009). Hemrom and Nema (2015) reported cultivation of Jamun tree species in traditional agroforestry systems such as agrisilviculture, agri-horti-silviculture, acqua-forestry in Bastar region of Chhattisgarh. Chavan et al. (2015) reported Jamun under restricted species category which requires permission for felling in Madhya Pradesh and Jharkhand states of India; whereas permission is not required in Andhra Pradesh. Jamun is one fruit tree component of agri-horticulture system reported by Choudhary et al. (2012) in Rajouri District of Jammu and Kashmir. Kashyap et al. (2014) reported that Jamun is an important fruit tree component of traditional fruit based agroforestry systems, India.

However, species has such a tremendous potential for upliftment of small land holding farmers of the salt affected waterlogged areas, it is not used widely in commercial agroforestry systems. This paper emphasized on species production and protection services, which strengthening the potential of species in agroforestry systems for improving condition of small land holding farmers of India.

\section{PRODUCTION SERVICES}

Breaking the food insecurity circle: The situation that exists when there insufficient availability of safe and nutritious food to meet their dietary needs and food preferences for an active and healthy life known the food insecurity. Increasing crop productivity on farm is not only the solution for breaking the poverty and food insecurity circle; we have to go for another option such as domestication of MPTs on farm lands (Sarvade et al., 2014). Through increasing diverse food production, resource conservation, employment generation and enhancing rural income, agroforestry systems may solve food insecurity problems. Domestication of an indigenous wild fruit tree species in unproductive and degraded areas in traditional agroforestry systems for providing nutritious food production (Anonymous, 2013). Agroforestry MPTs provide important ecosystem services such as improvement of soil properties; spring, stream and watershed protection; biodiversity conservation; and carbon sequestra- tion and storage, all of which ultimately affect food and nutritional security (Garrity 2004; Sarvade and Singh, 2014).

Jamun tree species is widely used in traditional agroforestry systems in India. Fresh ripe fruits of Jamun are juicy, almost odourless with a pleasant, slightly bitter, astringent taste usually eaten (Das and Das, 2005; Swami et al., 2012; Dangwal et al., 2014; Kashyap et $a l ., 2014)$. The nutrient value of Jamun fruits is given in table 1 . They may also be processed into jams, jellies, juice and puddings (Chaudhary and Mukhopadhyay, 2012; Sekhar et al., 2015). Jamun fruits are not only widely consumed as regular food supplement to diet but also add variety to diets, improve palatability and provide essential vitamins, minerals, proteins and calories (Choudhary et al., 2012).

Fodder: Their leaves commonly use as fodder (Das and Das, 2005; Yadav and Bisht, 2013; Kashyap et al., 2014); flowers are rich in nectar and yield high-quality honey.

Fuelwood: It is a fast-growing tree, which provides excellent firewood and charcoal. Wood produced has a specific gravity of 0.77 and burns well, giving off about $4800 \mathrm{kcal} / \mathrm{kg}$ (Orwa et al., 2009). Mushtaq et al. (2012) reported Jamun as an important tree species for fuelwood consumption across the 12 villages viz. Parmandal, Madana, Sadral, Paddal, Kothar, Mandal, Kalarian, Parri, Abtal, Gokhal, Chakh, Bandral and Keso villages respectively of Samba district of Jammu \& Kashmir. Mbwambo et al. (2013) reported Jamun as fuel wood tree species in agroforestry systems of $\mathrm{Mu}-$ soma Rural District, Mara Region, Tanzania.

Timber: Moderately hard, rough, strong, durable; lasts well under water. The bending strength of dry wood is $1343 \mathrm{~kg} / \mathrm{cm}^{2}$. The density of dry wood is $641 \mathrm{~kg} / \mathrm{m}^{3}$. The hardness of dry wood is $671 \mathrm{~kg} / \mathrm{cm}^{2}$.The hearing strength of dry wood is $709 \mathrm{~kg} / \mathrm{m}^{2}$. The shearing strength of dry wood is $167 \mathrm{~kg} / \mathrm{m}^{2}$ (Patil et al., 2014). The heartwood is reddish-grey or reddish-brown and fine grained; may be utilized in exterior joinery and carpentry work. Wood is durable in water, resistant to termites, and although difficult to work, it saws and machines well and is used for construction, boat building, commercial tea and chest plywood, agricultural implements, tool handles, cart wheels, well curbs and troughs, sleepers, furniture and as props for shafts and galleries in mines. It is also used for building bridges and for making musical instruments, especially guitars (Das and Das, 2005; Orwa et al., 2009; Kashyap et al., 2014). Bark of Jamun has served in tanning and yields a brown dye that has been used in colouring fishnets. Fruits are used to make wine (Orwa et al., 2009).

Medicine: It has been valued in Ayurveda and Unani system of medication for possessing variety of therapeutic properties. Important chemicals from the different parts of plant are given in Table 2. Most of the plant parts are used in traditional system of medicine 
in India (Table 3). Fruits are used as a relief for colic, while the wood yields a sulphate pulp that has medicinal uses in stomach-ache and enlarged spleen (Sharma et al., 2014). The seeds and bark are well known in the Far East for the treatment of dysentery and in control of hyperglycaemia and glycosuria in diabetic patients (Rahman, 2013). According to Ayurveda, its bark is acrid, sweet, digestive and astringent to the bowels, anthelmintic and in good for sore throat, bronchitis, asthma, thirst, biliousness, dysentery, blood impurities, astringent bark may be used as a gargle and to cure ulcers. In Unani medicine system the ash of leaves is used for strengthen the teeth and the gums, the seeds are astringent, diuretic, stops urinary discharge and remedy for diabetes which reduce the blood sugar level quickly, and the barks showed good wound healing properties (Orwa et al., 2009; Swami et al.,2012; Agarwal et al., 2015).

\section{PROTECTION SERVICES}

Being an evergreen species, abundant foliage of Jamun produces good shade, which has been used to shelter coffee trees, chicken yards and livestock pastures.

Table 1. Jamun fruit nutritional value per $100 \mathrm{~g}$ (3.5 oz).

\begin{tabular}{lc}
\hline Particular & Values \\
\hline Energy & $251 \mathrm{~kJ}(60 \mathrm{kcal})$ \\
Carbohydrates & 15.56 \\
Dietary fibre & $0.3-0.9 \mathrm{~g}$ \\
Fat & $0.15-0.30 \mathrm{~g}$ \\
Protein & $0.72 \mathrm{~g}$ \\
Vitamins & \\
Thiamine (B1) & $(1 \%) 0.006 \mathrm{mg}$ \\
Riboflavin (B2) & $(1 \%) 0.012 \mathrm{mg}$ \\
Niacin (B3) & $(2 \%) 0.260 \mathrm{mg}$ \\
Pantothenic acid (B5) & $(3 \%) 0.160 \mathrm{mg}$ \\
Vitamin B6 & $(3 \%) 0.038 \mathrm{mg}$ \\
Vitamin C & $(17 \%) 14.3 \mathrm{mg}$ \\
Trace minerals & $(2 \%) 19.00 \mathrm{mg}$ \\
Calcium & $(1 \%) 0.19 \mathrm{mg}$ \\
Iron & $(4 \%) 15.00 \mathrm{mg}$ \\
Magnesium & $(2 \%) 17.00 \mathrm{mg}$ \\
Phosphorus & $(2 \%) 79.00 \mathrm{mg}$ \\
Potassium & $(1 \%) 14.00 \mathrm{mg}$ \\
Sodium & \\
Other constituents & $83.70-85.80 \mathrm{~g}$ \\
Water &
\end{tabular}

When closely planted in rows, trees make good windbreaks. It is one of the most popular avenue trees and widely planted along road lines in India. Jamun is successfully planted in waterlogged areas. Trees planted close together and topped regularly form a dense hedge.

Biomass production and carbon sequestration potential: The potential of agroforestry systems for sequestering $\mathrm{C}$ and producing biomass for biofuels like many other land use systems was reported by (Jose and Bardhan, 2012). Jamun produces 1.59-17.04 t/ha aboveground biomass, $0.42-4.53$ t/ha belowground biomass and 2.01-21.57 t/ha total biomass in traditional agroforestry system of Garhwal Himalaya (Kumar et al., 2012). Ullah and Al-Amin (2012) reported $7.43,1.11$ and 8.55 t/ha aboveground, belowground and total biomass, respectively in natural forest. Above ground biomass of Jamun tree species was 132.59 $\mathrm{Mgha}^{-1}$ in tree plantations at Kurukshetra in Northern India (Arora and Chaudhry, 2014). The 30.82 $\mathrm{t} \mathrm{ha}^{-1}$ total biomass production from $S$. cuminii in dry tropical forest, India (Pawar et al., 2014).

Traditional agroforestry system of Garhwal Himalaya, Jamun conserve 0.716-7.67, 0.190-2.04 and 0.906-9.71 t/ha above, below and total carbon stock (Kumar et al., 2012). The 3.73, 0.56 and 4.29t/ha above, below and total carbon stock was reported by Ullah and Al-Amin (2012) in natural forest. Chauhan et al. (2009) reported $0.73 \mathrm{t} / \mathrm{ha}$ carbon storage at the plantation level in Punjab, India, whereas $1.43 \mathrm{t} / \mathrm{ha}$ carbon added to the soil through roots and litter decomposition. Pragasan et al. (2015) reported highest carbon stock stored by $S$. cumini followed by Anogeissus latifolia, Prumus ceylanica, Terminalia paniculata and Tamarindus indica in Shervarayan Hills, India. Dry tropical forest, India stores $13.471 \mathrm{t} \mathrm{ha}^{-1}$ total carbon by S.cuminii species (Pawar et al., 2014).

Soil improvement and reclamation of degraded areas: Litter addition, decomposition and nutrient release, nutrient addition through root biomass and controlling soil erosion were important processes for improvement of soil properties (Sarvade et al., 2014). Keystone species (e.g. Englehardtia spicata, Echino-

Table 2. Phytochemicals present in the different parts of Jamun plant.

\begin{tabular}{|c|c|c|}
\hline S. N. & Plant part & Chemicals present \\
\hline 1 & Seeds & $\begin{array}{l}\text { Jambosine, Gallic acid, Ellagic acid, Corilagin, 3,6-hexahydroxy diphenoylglucose, 1-galloylglucose, } 3 \\
\text {-galloylglucose, Quercetin, } \beta \text {-sitoterol, 4,6 hexahydroxy diphenoyl glucose, Essential oils }\end{array}$ \\
\hline 2 & Stem bark & $\begin{array}{l}\text { Tannins, Resin, Phytosterols, Friedelin, Friedelan-3- } \alpha \text {-ol, Betulinic acid, } \beta \text {-sitosterol, Kaempferol, } \beta \text { - } \\
\text { sitosterol-Dglucoside, Gallic acid, Ellagic acid, Gallotannin and Ellagitannin and Myricetine }\end{array}$ \\
\hline 3 & Flowers & Terpenoids, Oleanolic acid, Ellagic acids, Isoquercetin, Quercetin, Kampferol and Myricetin \\
\hline 4 & Fruit pulp & $\begin{array}{l}\text { Vitamin-C, Vitamin-A, Riboflavin, Nicotinic acid, Choline, Folic acid, Malaic acid, Sugar, Amino } \\
\text { acids, } \mathrm{Na}, \mathrm{K}, \mathrm{Ca}, \mathrm{P}, \mathrm{Fe}, \mathrm{Zn}, \mathrm{Mn} \text {, Anthocyanins, Delphinidin, Petunidin, Malvidin-diglucosides }\end{array}$ \\
\hline 5 & Leaves & $\begin{array}{l}\beta \text {-sitosterol, Betulinic acid, Mycaminose, Crategolic (maslinic) acid, n-hepatcosane, n-nonacosane, n- } \\
\text { hentriacontane, Noctacosanol, n-triacontanol, n-dotricontanol, Quercetin, Myricetin, Myricitrin and the } \\
\text { Flavonol glycosides myricetin 3-O-(4"-acetyl)- } \alpha \text { Lrhamnopyranosides, Essential oils }\end{array}$ \\
\hline 6 & Essential oils & $\begin{array}{l}\alpha \text {-terpeneol, Myrtenol, Eucarvone, Muurolol, } \alpha \text {-myrtenal, } 1,8 \text {-cineole, Geranyl acetone, } \alpha \text {-cadinol and } \\
\text { Pinocarvone }\end{array}$ \\
\hline
\end{tabular}

Source: Swami et al. (2012); Chaudhary andMukhopadhyay, (2012). 
Table 3. Plant part used, mode of preparation, administration and ailments treatment by ethnic groups of India.

\begin{tabular}{|c|c|}
\hline $\begin{array}{l}\text { Ethnic group used and } \\
\text { their origin }\end{array}$ & Plant part used, mode of preparation and disorders treatment \\
\hline $\begin{array}{l}\text { Lakher and Pawi in North } \\
\text { east India }\end{array}$ & $\begin{array}{l}\text { Infusion of fruit or mixture of powdered bark and fruit is given orally to treat diabetes. } \\
\text { Juice obtained from the seeds is applied externally on sores and ulcers. } \\
\text { Powdered seeds are mixed with sugar are given orally } 2-3 \text { times daily in the treatment of } \\
\text { dysentery. } \\
\text { The juice of leaves is given orally as antidote in opium poisoning and in centipede bite. } \\
\text { The juice of ripe fruits is stored for } 3 \text { days and then is given orally for gastric problems. } \\
\text { The juice obtained from the bark is given orally for the treatment of women with a history of } \\
\text { repeated abortion. }\end{array}$ \\
\hline $\begin{array}{l}\text { Local informants in Ma- } \\
\text { harastra, India }\end{array}$ & $\begin{array}{l}\text { Fruit and stem bark are used in the treatment of diabetes, dysentery, increases appetite and to } \\
\text { relieve from headache }\end{array}$ \\
\hline $\begin{array}{l}\text { Nepalese, Lepchas and } \\
\text { Bhutias innortheast India }\end{array}$ & Decoction of stem bark is taken orally three times a day for 2-3 weeks to treat diabetes. \\
\hline Kanitribals in Southern India & $\begin{array}{l}\text { Two teaspoon of juice extracted from the leaf is mixed with honey or cow's milk and taken } \\
\text { orally taken twice a day after food for } 3 \text { months to treat diabetes. } \\
\text { Fresh fruits are also taken orally to get relief from stomach ache and to treat diabetes. } \\
\text { Young leaf is ground into a paste with goat's milk and taken orally to treat indigestion. }\end{array}$ \\
\hline Malayalis in South India & $\begin{array}{l}\text { Paste of seeds is prepared with the combination of leaves of Momordica charantia and flow- } \\
\text { ers of Cassia auriculata and taken orally once a day for } 3 \text { months to treat diabetes. }\end{array}$ \\
\hline $\begin{array}{l}\text { Local population in Andhra } \\
\text { Pradesh, India }\end{array}$ & $\begin{array}{l}\text { Shade dried seeds are made into powder and taken orally thrice a day in the treatment of } \\
\text { diabetes. }\end{array}$ \\
\hline Siddis in Karnataka, India & $\begin{array}{l}\text { The juice obtained from the leaves is mixed with milk and taken orally early in the morning, } \\
\text { to treat diabetes. } \\
\text { The juice obtained from the stem bark is mixed with butter milk and taken orally every day } \\
\text { before going to bed to treat constipation. } \\
\text { The same recipe, when taken early in the morning on an empty stomach, is claimed to stop } \\
\text { blood discharge in the faeces. }\end{array}$ \\
\hline Tribal people in Maharastra & $\begin{array}{l}\text { The tender leaves are taken orally to treat jaundice. } \\
\text { It was claimed that the eyes, nails and urine turned yellow. } \\
\text { The treatment was followed for } 2-3 \text { days by adults and children as well. }\end{array}$ \\
\hline
\end{tabular}

Source :(Ayyanar and Subash-Babu, 2012)

carpus dasycarpus, S. cuminii and Drimycarpus racemosus) conserve high levels of nitrogen, phosphorus and potassium in highly infertile soils within a sacred grove in northeast India (Ramakrishnan, 2001).

Mycorrhizal fungi form symbiotic relationship with plants and have a potential for the improvement of soil $\mathrm{P}$ content. The nine year old plant of Jamun colonize 48.2 per cent VAM (Vesicular-Arbuscular Mycorrhiza) in agroforestry systems of Karnataka (Lakshman et al., 2001).

Vulnerability and tolerance of any species for the salt affected soil depends on their early growth under such adverse conditions. Tomar et al. (2003) reported satisfactory early growth and survival with application of saline irrigation water. The reclamation of salt affected soils by planting of different multipurpose tree species. The Jamun grow well under saline soils (Behera et al., 2015). Dhillon et al. (2008) reported the potential of Jamun tree species for phytoremediation of seleniferous soils in the village Barwa of Nawanshahar district, Punjab. Kumar et al. (2010) reported potential of Jamun in reclamation and re-vegetation of coal mine spoils in Singrauli district of Madhya Pradesh, India.

Biodiversity conservation: Agroforestry is a complex system, in which woody perennial including tree, shrub, bamboo and palm species are deliberately grown with annual crop species, grasses simultaneously and sequentially and managed on same piece of land management unit. Being a complex system, it helps in conservation of biodiversity of an area (Sarvade, 2014). Das and Das (2005) reported total 122 plant species with fruits as the dominant usecomponent in traditional agroforestry system (home garden) Barak Valley, Assam, North East India. Traditional agroforestry systems in North Western Himalaya reported by Yadav and Bisht (2013) to conserve MPTs. Rahman (2013) reported ethnobotanical knowledge of rural community is the basis for biodiversity conservation. Total number of 107 different plant species ( 27 herbs, 15 shrubs, 7 climbers and 58 trees) belonging to 48 families and 87 genus were recorded by Sahoo et al. (2010) in the study of structural diversity of traditional home gardens of northeast India.

\section{Conclusion}

Jamun is MPTs widely intercropped in traditional fruit tree based agroforestry systems of India. The plant parts such as fruit pulp, seed, leaves, bark and flowers contain different chemicals which are most important in curing diabetes patient, dysentery and hyperglycaemia problems. The species yields nutritive fruits while growing on waste land or on farm lands. It helps in 
breaking food insecurity circle. Species produce 2.01$132.59 \mathrm{t} / \mathrm{ha}$ total biomass in agroforestry systems and tree plantations. It conserves $0.906-13.471$ t/ha total carbon. In conservation processes, it improves salt affected soils, produce biomass and store carbon in vegetation as well as in soil. It also helps in conserving biodiversity in traditional agroforestry systems and natural forests of India, which accelerates upliftment of small land holding farmers.

\section{ACKNOWLEDGEMENTS}

Authors would like to thanks Dean, College of Agriculture, Balaghat for encouraging and providing assistance writing the article.

\section{REFERENCES}

Agarwal, A. K., Goyal, P., Lakshminarasimhaiah, Goyal, P. and Singh, G. K. (2015). Pharmacognostical studies on a tropical plant, Syzygium cuminii Linn from Jodhpur District, Rajasthan, North West India. World Journal of Pharmacy and Pharmaceutical Sciences, 4(2): 1023-1030.

Anonymous. (2013). Agroforestry, food and nutritional security. World Agroforestry Centre (ICRAF), Nairobi, Kenya. pp.1-20.

Arora, P. and Chaudhry, S. (2014). Carbon sequestration in tree plantations at Kurukshetra in Northern India. American International Journal of Research in Formal, Applied \& Natural Sciences, 5(1): 65-70.

Ayyanar, M. and Subash-Babu, P. (2012). Syzygium cuminii (L.) Skeels: A review of its phytochemical constituents and traditional uses. Asian Pac. J. Trop. Biomed., 2(3): 240-246.

Behera, L., Nayak, M. R., Patel, D., Mehta, A., Sinha, S. K. and Gunaga, R. (2015). Agroforestry practices for physiological amelioration of salt affected soils. Journal of Plant Stress Physiology, 1(1): 13-18.

Chaudhary, B. and Mukhopadhyay, K. (2012). Syzygium cuminii (L.) Skeels: a potential source of nutraceuticals. International Journal of Pharmacy and Biological Sciences, 2(1): 46-53.

Choudhary, P., Tandon, V. and Sharma, R. (2012). Traditional agroforestry practices for sustainable livelihood in Rajouri district of Jammu and Kashmir. Journal of Tree Sciences, 31 (1\&2): 102-107.

Chauhan, S. K., Gupta, N., Yadav, R. S. and Chauhan, R. (2009). Biomass and carbon allocation in different parts of agroforestry tree species. Indian Forester, 135(7): 981-993.

Chavan, S. B., Keerthika, A., Dhyani, S. K., Handa, A. K., Ram Newaj and Rajarajan, K. (2015). National agroforestry policy in India: a low hanging fruit. Current Science, 108(10): 1826-1834.

Dangwal, L. R., Singh, T. and Singh, A. (2014). Exploration of wild edible plants used by Gujjar and Bakerwal tribes of District Rajouri (J\&K), India. Journal of Applied and Natural Science, 6 (1): 164-169.

Das, P. and Das, A. K. (2005). Inventorying plant biodiversity in homegardens: A case study in Barak Valley, Assam, North East India. Current Science, 89 (1): 155-163.

Dhillon, K. S., Dhillon, S. K. and Thind, H. S. (2008). Evaluation of different agroforestry tree species for their suitability in the phytoremediation of seleniferous soils. Soil Use and Management, 24: 208-216.

Garrity, D. P. (2004). Agroforestry and the achievement of the millennium development goals. Agroforestry Systems, 61: 5-17.

Hemrom, A. and Nema, S. (2015). A study on traditional agroforestry practices existing at Bastar region of Chhattisgarh. International Journal of Multidisciplinary Research and Development, 2(3): 56-64.

Jose, S. and Bardhan, S. (2012). Agroforestry for biomass production and carbon sequestration: an overview. Agroforest Syst., 86: 105-111.

Kashyap, S. D., Dagar, J. C., Pant, K. S. and Yewale, A. G. (2014). Soil conservation and ecosystem stability: natural resource management through agroforestry in Northwestern Himalayan region. In: Agroforestry systems in India: livelihood security \& ecosystem services, advances in agroforestry, Dagar J. C. et al. (eds.). pp. 21-55.

Kumar, A., Raghuwanshi, R. and Upadhyay, R. S. (2010). Arbuscular mycorrhizal technology in reclamation and re-vegetation of coal mine spoils under various revegetation models. Engineering, 2: 683-689.

Kumar, M., Anemsh, K., Sheikh, M. A. and Raj, A. J. (2012). Structure and carbon stock potential in traditional agro forestry system of Garhwal Himalaya. Journal of Agricultural Technology, 8(7): 2187-2200.

Lakshman, H. C., Rajanna, L., Inchal, R. F., Mulla, F. I. and Srinivasulu, Y. (2001). Survey of VA - mycorrhizae in agroforestry and its implications on forest trees. Tropical Ecology, 42(2): 283-286.

Luna, R. K. (2005). Plantation Trees. International Book Distributors, Dehradun. pp 728-733.

Mbwambo, J. S., Saruni, P. L. and Massawe, G.S. (2013). Agroforestry as a solution to poverty in rural Tanzania: lessons from Musoma Rural District, Mara Region, Tanzania. Kivukoni Journal, 1(2): 15-30.

Mushtaq, T., Sood, K. K. and Raina, N. S. (2012). Species preferences for fuelwood in Shiwalik Himalayas- implications for agroforestry plantations. Indian Journal of Hill Farming, 25(2):18-21.

Orwa, C., Mutua, A., Kindt, R., Jamnadass, R. and Anthony, S. (2009) Agroforestry tree Database: a tree reference and selection guide version 4.0 (http://www.worldagroforestry.org/ sites/treedbs/treedatabases.asp)

Patil, P.V., Kulkarni, D. K. and Nipunage, D.S. (2014). Wisdom of local people on selection of wood for agricultural implements from Bhor and Mahad regions of Western Maharashtra.Indian Journal of Advances in Plant Research, 1(2): 11-17.

Pawar, G. V., Singh, L., Jhariya, M. K. and Sahu, K. P. (2014). Effect of anthropogenic disturbances on biomass and carbon storage potential of a dry tropical forest in India. Journal of Applied and Natural Science, 6 (2): 383-392.

Pragasan, L. A. (2015). Total carbon stock of tree vegetation and its relationship with altitudinal gradient from the Shervarayan hills located in India. J. Earth Sci. Clim. Change, 6(4): 1-5.

Rahman, M. H. (2013). A study on exploration of ethnobotanical knowledge of rural community in Bangladesh: basis for biodiversity conservation. ISRN Biodiversity, 2013: 1-10.

Ramakrishnan, P. S. (2001). Increasing population and declining biological resources in the context of global 
change and globalization. J. Biosci., 26(4): 465-479.

Roy, P. S., Behera, M. D., Murthy, M. S. R. et al. (2015). New vegetation type map of India prepared using satellite remote sensing: comparison with global vegetation maps and utilities. International Journal of Applied Earth Observation and Geoinformation, 39: 142-159.

Sahoo, U. K., Rocky, P., Vanlalhriatpuia, K. and Upadhyaya, K. (2010). Structural diversity and functional dynamism of traditional home gardens of North-East India. The Bioscan, 1: 159-171.

Sarvade, S. (2014). Agroforestry: refuge for biodiversity conservation. International Journal of Innovative Research in Science \& Engineering, 2(5): 424-429.

Sarvade, S. and Singh, R. (2014). Role of agroforestry in food security. Popular Kheti, 2(2): 25-29.

Sarvade, S., Singh, R., Prasad, H. and Prasad, D. (2014). Agroforestry practices for improving soil nutrient status. Popular Kheti, 2(1): 60-64.

Sarvade, S., Singh, R., Ghumare, V., Kachawaya, D. S. and Khachi, B. (2014). Agroforestry: an approach for food security. Indian J. Ecol., 41(1): 95-98.

Sharma, A. K., Bajpai, S., Shrivastava, S. and Kanungo,V.
K. (2014). Inventorying medicinal plants in urban homegardens of Raipur, Chhattisgarh. International Journal of Herbal Medicine, 2 (1): 43-50.

Sekhar, C., Rajesh, R. and Vani, V. (2015). Role of Jamun (Syzygium cuminii) in enhancing the agripreneurial status of a farmer - a case study in Dindigul district of Tamil Nadu. Journal of International Academic Research for Multidisciplinary, 3(2): 270-290.

Swami, S. B., Thakor, N.S. J., Patil, M. M. and Haldankar, P. M. (2012). Jamun (Syzygium cuminii (L.): A review of its food and medicinal uses. Food and Nutrition Sciences 3: 1100-1117.

Tomar, O. S., Minhas, P. S., Sharma, V.K., Singh, Y. P. and Gupta, R. K. (2003). Performance of 31 tree species and soil conditions in a plantation established with saline irrigation. Forest Ecology and Management, 177: 333-346.

Ullah, R. and Al-Amin, M. (2012). Above- and belowground carbon stock estimation in a natural forest of Bangladesh. Journal of Forest Science, 58(8): 372-379.

Yadav, R. P. and Bisht, J.K. (2013). Agroforestry: A way to conserve MPTs in North Western Himalaya. Research Journal of Agriculture and Forestry Sciences, 1(9): 8-13. 